\title{
POLITICALLY CONNECTED, INTERNAL GOVERNANCE MECHANISMS AND AUDIT FEES IN MALAYSIA
}

\author{
I. K. Norziaton*, S. Susela Devi, \& Chan Wai Meng
}

\begin{abstract}
This research is conducted in the Malaysian corporate setting with the presence of favoured companies or politically connected companies (PCON). PCON companies are perceived by the market and external auditors to be riskier than non-politically connected companies. In addition, these companies generally exhibit poor corporate governance practices and face agency problems. However, the enforcement of tighter regulations and the greater emphasis on risk management and governance practices within the PCON companies further indicate the growing importance of having a strong audit committee and internal audit functions in fulfilling corporate governance responsibilities. With reference to the findings from the interviews with the regulators, external auditors and internal auditors, the audit committee and the head of internal auditors of PCON companies have been complying with the Bursa Malaysia Listing Requirements, which were revised in 2008. This observation strengthens claims that the corporate governance regulatory framework has indeed been effective. The involvement of the audit committee and internal audit functions in strengthening internal controls demand higher audit quality from the external auditors, and, hence, higher audit fees.
\end{abstract}

Keywords: Audit Committee, Audit Fee, Corporate Governance, Internal Audit Function, Politically Connected Companies

JEL Classification: M41, M42, M48

\section{Introduction}

Economies with efficient economic policies and stable political systems are a big draw for investors. Countries that have opened themselves to the global markets and that have good legal systems in place attract more capital in the process of globalization (Abdul Rahman, 2006). However, before investors decide to invest their funds in a particular business, they want to be assured that the business is financially sound and will continue to be so in the foreseeable future (Abdul Rahman, 2006). Investors need to have confidence that the business is well managed and will continue to be profitable. In the era of globalization and open

*Corresponding Author: Norziaton Ismail Khan, $P h D$ is a Senior Lecturer at the Faculty of Accountancy, MARA University of Technology. Email: norzi153@salam.uitm.edu.my.

S. Susela Devi, PhD is a Professor at the Faculty of Business Technology and Accounting, UNITAR International University. Email: susela@unitar.my

Chan Wai Meng, PhD is an Associate Professor at the Faculty of Business and Accountancy, University of Malaya. Email: chanwm@um.edu.my 
market economy, Malaysia is exposed to intense competition from other nations. Malaysia has a unique corporate environment that offers clearly identifiable segments of ethnic, politically connected (PCON) companies (Haniffa \& Cooke, 2002; Gul, 2006; Yatim et al., 2006) and government-linked companies ${ }^{\dagger}$ (Najid \& Abdul Rahman, 2011) [in this study government-linked companies with political connections are collectively referred to as politically connected companies or PCON companies]. PCON companies are companies identified as having political connections with key government officials (see Gomez \& Jomo, 1999; Johnson \& Mitton, 2003; Mohamad, Hassan, \& Chen, 2006; Abdul Wahab, Mat Zain, James, \& Haron, 2009). It is also generally accepted that Malaysia has favoured companies as a result of the government's intention to increase Bumiputra equity in the country (Gomez \& Jomo, 1999; Gul, 2006).

As observed in the World Bank Report in 2005, the high level of government equity ownership is seen as a challenge to enhancing good corporate governance in Malaysia. Several corporate governance studies prior to $2007 \mathrm{had}$ investigated the government-linked companies, and companies with political connections were found to be more risky (Gul, 2006). They are said to be favoured companies (Gomez \& Jomo, 1999; Johnson \& Mitton, 2003; Gul, 2006), and, generally, are perceived to exhibit poor corporate governance and greater agency problems (Abdul Wahab et al., 2009). In this context, the political embeddedness perspective may be pertinent to explain the corporate setting in Malaysia, where there is a close link between selected large companies or conglomerates and the government of the day (Hadjikhani \& Håkansson, 1996). These politically connected companies have exclusive business relationships with the state-owned enterprises and have the ability to access the government's major contracts (Gomez \& Jomo, 1999). The analysis in Johnson and Mitton (2003) provides insights that stock returns of politically connected companies are lower in comparison with other Malaysian companies. They observe that politically connected companies suffered the most during the early stages of the Asian financial crisis in 1997 assuming that the government was unable to implement capital controls. However, once capital controls ${ }^{\ddagger}$ were imposed, on average, the returns of these favoured companies were higher (Johnson \& Mitton, 2003).

To date, Malaysia has made significant progress in developing an efficient and well-regulated capital and financial market, as well as strengthening the institutional framework for the regulation of the accounting and auditing profession (World Bank, 2012). Good progress has been achieved in improving the quality and consistency of corporate financial reporting and corporate governance (CG) for listed companies. The corporate governance landscape in

\footnotetext{
${ }^{\dagger}$ Government-linked firms are defined as firms that have a primary commercial objective and in which the Malaysian Government has a direct controlling stake through Khazanah, Ministry of Finance (MOF), Kumpulan Wang Amanah Pencen (KWAP), and Bank Negara Malaysia (BNM) [Putrajaya Committee GLC (PCG) high performance, (2007)]

${ }^{*}$ The Government's implementation of capital controls in 1998 was primarily to benefit politicallyconnected firms that were adversely affected by the Asian financial crisis in 1997.
} 
Malaysia has transformed significantly as companies accentuated their corporate governance efforts. In 2007 the Securities Commission (SC) released the revised code on corporate governance to further strengthen Malaysia's corporate governance framework, aligning it with the then current globally accepted best practices. The Malaysian Code on Corporate Governance (MCCG, Revised 2007), which superseded the earlier Code issued in March 2000, contains recommendations that aim to strengthen the roles and responsibilities of boards of directors and audit committees to ensure that they discharge their duties effectively. Subsequently, Bursa Malaysia revamped its listing requirements in 2008, which called for increased interaction between the internal governance mechanisms of the audit committee and the internal audit function.

Since PCON companies are perceived to be riskier than non-PCON companies, it is reasonable to expect PCON companies to implement good governance system to improve the compliance level, and, consequently, to protect their reputational capital. Furthermore, good governance practices help to reduce audit risk due to business failure or the likelihood of financial misreporting. In addition, institutional investors also play a role in promoting corporate transparency for PCON companies (How et al., 2014). Having good governance indicates a demand for substantive audit testing from auditors and a reliable financial statement audit. Prior studies on PCON companies have generally drawn on the supply based perspective suggesting a supply-side explanation for audit fees in the absence of a strong corporate governance regime. Given the enhanced corporate governance reforms since 2007, this research investigates the impact on the audit fees for PCON companies from the implementation of the internal governance mechanisms post-BMLR 2008.

\section{Literature Review: Internal Governance Mechanisms and Audit Fees}

Good corporate governance is essential for economic stability and growth in developed and developing economies. Enhanced corporate governance is likely to have an effect on audit fees because improved corporate governance implies that the control environment is more effective (Hay et al., 2008). Further, improving governance through improving the board or the audit committee will lead to more external auditing (Hay, 2012). They may demand more testing as the statutory audit is one of the important corporate governance tools for shareholders to monitor the managers. Thus, companies with strong governance structures tend to spend more on auditing (Hallak \& Silva, 2012). This study uses the agency theory framework to examine the impact of having an audit committee that is independent and diligent, and possesses accounting expertise, in representing the interests of corporate owners as a counter to the potential self-interests of management. Applying this to a corporate setup, managers have a conflict of interests with those of the shareholders. The managers, as agents, may be working to maximize their own personal gains rather than maximizing 
shareholders' value. As internal governance mechanisms, both the audit committee and internal audit function can increase the monitoring of management and reduce the incidence of irregularities in the financial reporting. Basically, the issues can be viewed from two different perspectives; the governance risk or supply based perspective, and the demand based perspective.

From the governance risk perspective (supply based perspective), researchers argue that corporate governance is associated with lower audit fees (Bedard et al., 2004). The reason for this is that external auditors respond to client risks through appropriate audit procedures. Auditors who perceive lower risks will reduce their audit effort, resulting in lower audit fees. Prior studies (see Beasley, 1996; Dechow, Sloan, \& Wong, 1996; Klein, 2002; Abbott et al., 2004; Krishnan \& Ye, 2005) observe that the strength of the board of directors and audit committee is significantly associated with the quality of the internal controls and financial reports. Auditors will have greater assurance of the internal controls and compliance, and reduced likelihood of material misstatement in financial reports if they perceive a strong and independent board and audit committee. In such cases, the auditors may reduce their audit effort, resulting in lower audit fees. Conversely, if auditors perceive higher client risks, then the audit effort and fees may be increased Chung and Wynn (2014).

In contrast, from a demand based perspective, researchers propose that higher quality corporate governance structures demand more external monitoring, and, thus, companies are willing to pay for higher quality audits. Similarly, directors with greater reputational capital at risk will demand substantive audit testing from external auditors in order to protect their reputational capital and reduce the risk of litigation (O'Sullivan, 1999 and 2000; Carcello et al., 2002; Abbott et al., 2003; Goodwin \& Kent, 2006). Supported by Bedard et al. (2004), auditors will strategically respond to client risks through appropriate adjustments to the audit procedures. In addition, Fields, Fraser, and Wilkins (2004) suggest that strong internal monitoring by the audit committee reduces the risks inherent in banking institutions that could manifest in audit efficiencies. Thus, auditors who observe higher client risks would increase their audit effort, resulting in higher audit fees. A review of the empirical studies on the relationship between audit committee characteristics and external audit fees shows mixed results. Abbott et al., (2003) document that audit committee independence, and financial expertise have significant positive impact on the cost of the audit. However, Carcello et al. (2002) find that the characteristics of the board of director's independence, diligence and expertise but not the audit committee are positively associated with audit fees. The results from Lifschutz, Jacobi, and Feldstein's (2010) study on 60 large public companies on the Tel Aviv 100 Stock Exchange Index show that board independence and audit committee diligence are positively and significantly associated with audit fees.

Similarly, studies have been done in Malaysia on the effect of the audit committee as a governance mechanism on audit fees. The results by Yatim et al. (2006) show that external audit fees are positively and significantly associated with board independence, audit committee expertise and the frequency of audit 
committee meetings. Again, the results are consistent with the demand-side approach for audit services, wherein companies with good corporate governance attributes demand higher audit quality, resulting in higher external audit fees. Interestingly, in terms of corporate governance and Bumiputra-controlled companies, Yatim et al. (2006) find evidence that Bumiputra-controlled companies practice favourable corporate governance more than non-Bumiputra companies. This shows that Bumiputra controlled companies practice improved internal corporate governance as compared to their non-Bumiputra counterparts. The findings by Gul (2006) and Abdul Wahab et al. (2009 and 2011) on audit fees for politically connected companies, and Yatim et al. (2006) on the audit fees for Bumiputra-controlled companies were based on the data prior to the implementation of BMLR 2008. Thus, it is important to determine whether the findings hold even after the corporate governance reform was carried out in 2008 since the political connection between the companies and government plays an important role in audit risk assessment (Liu \& Subramaniam, 2013).

With reference to the internal audit function, prior studies generally suggest that internal control and external auditing can substitute for each other, so that better internal control will be associated with lower audit fees (Hay et al., 2008). In addition, several other studies argue that better internal control will allow external audit work to be reduced, for instance, control mechanisms in an organization can be substituted one for another (Simunic, 1980), and this could lead to lower audit fees. Prawitt et al. (2008) highlight that a high-quality internal audit function (IAF) also results in lower external audit fees. In contrast, past research has examined the interaction between internal audit functions and external audit services and finds them to be complementary. From this demand side perspective, improved corporate governance is associated with higher audit fees. Walker and Casterella (2000) find that there is a positive relationship between external audit fees and the presence of an internal audit department. Other studies also find that the expected reduction in audit work does not occur even when auditors are able to rely on internal control (O'Keefe, Simunic, \& Stein, 1994; Hackenbrack \& Knechel, 1997). Hay et al. (2008) find that controls, governance, and auditing are complementary, not substitutes, and an increase in one will lead to an increase in the others. According to Goodwin and Kent (2006), audit fees are positively related to the use of an internal audit function because companies with strong corporate governance practices are likely to engage in greater levels of internal auditing and are also willing to pay for a higher quality of external audit work. It is still unclear whether the internal audit function plays a substitution or complementary role to external auditing, and thus, its implications for audit fees are inconclusive.

According to the World Bank Report on the Observance of Standards and Codes, audit fees charged in Malaysia are low when compared with other ASEAN member countries (World Bank, 2012, p.4). The Report further elaborates that the reasons for this reflect the price-competitive environment in which the audit profession has been operating in and the relatively low salaries paid to accounting professionals in Malaysia (particularly when compared with 
Singapore). The Report suggests that it is not uncommon for decisions on hiring auditors to be based primarily on the audit fee level. The concern raised by the World Bank is that, over time, this practice could have a significant impact on audit quality and potentially damage the reputation of the Malaysian audit profession as a whole. This study (which focuses on the audit fee phenomenon in Malaysia) is timely in response to the concerns raised by the World Bank Report 2012 regarding the low audit fees in Malaysia. Hence, in this study interviews are conducted with selected external auditors, heads of the internal auditors and regulators to ascertain the existence of the demand side explanation for the audit fees.

\section{Research Design}

The data of this study involves eight interviews with two regulators, three external auditors and three heads of internal auditors to elicit their perceptions concerning the revised BMLR 2008 on audit committee (AC) characteristics and internal audit function (IAF) attributes, and their implications for audit fees. They were chosen based on their in-depth understanding of the audit fees issue and its impact on other internal governance mechanisms, such as audit committee and internal audit function in PCON companies. The findings from the interviews are discussed under two (2) main themes. First, the interviews gathered their perceptions concerning whether the revised BMLR, 2008 on AC characteristics and IAF attributes affect audit fees. Secondly, the interviews focused on investigating the interviewees' perceptions concerning the effect of the enhanced listing requirements and audit fees for different types of ownership structured companies in Malaysia, specifically that of PCON companies. The findings from the interviews are discussed below.

\section{Results and Discussion}

An analysis of the background of the respondents was carried out. Of the respondents who participated in the interviews, the majority are males, and two are females. All eight respondents ${ }^{\S}$ hold an accounting qualification, and six of them also hold professional qualifications. Two of the participants are members of the Institute of Internal Auditors Malaysia (IIAM), and four are also members of the Malaysian Institute of Accountants (MIA). The respondents report having at least six years' experience in the accounting and auditing field. The data matrix framework, as provided in Table 1, compares and contrasts the perceptions of the internal auditors, external auditors, and regulators, respectively.

\footnotetext{
${ }^{\S}$ The respondents for the interviews in the current study are categorized as Internal Auditors (IA), External Auditors (EA), and Regulators (R).
} 
Table 1. Demographic details

\begin{tabular}{lcccccccc}
\hline $\begin{array}{l}\text { Demographic } \\
\text { Details }\end{array}$ & IA1 & IA2 & IA3 & EA1 & EA2 & EA3 & R1 & R2 \\
\hline Age group & $36-40$ & $46-50$ & $41-45$ & $36-40$ & $46-50$ & $36-40$ & $46-50$ & $36-40$ \\
$\begin{array}{l}\text { Gender } \\
\text { Professional }\end{array}$ & Male & Male & Male & Female & Male & Female & Male & Male \\
$\begin{array}{l}\text { Qualification/ } \\
\text { Membership }\end{array}$ & ICSA & CIA & MIA & MIA & MIA/ & MICPA & MIA/ & CISA/ \\
$\begin{array}{l}\text { No. of years } \\
\text { working }\end{array}$ & $>11$ & $>11$ & $>11$ & $>11$ & $>11$ & $6-10$ & $>11$ & $>11$ \\
experience & Years & Years & Years & Years & Years & Years & Years & Years \\
\hline
\end{tabular}

\subsection{Perceptions on the Internal Governance Mechanisms and Audit Fees}

In this section, the focus of the interviews is on the perceptions of the interviewees in terms of the enhanced BMLR 2008 on AC characteristics and IAF attributes, and its implications for audit fees. The audit committee is an important self-regulatory governance mechanism with significant oversight responsibilities for financial reporting, internal control and audit activities (BRC, 1999; SEC, 1999).

Table 2. Internal governance mechanisms and audit fees

\section{Content Theme: Perceptions on the enhanced CG on AC characteristics and IAF attributes and AF implications}

\begin{tabular}{|c|c|c|c|c|c|c|c|c|}
\hline 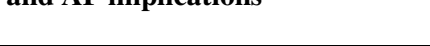 & IA1 & IA2 & IA3 & EA1 & EA2 & EA3 & R1 & R2 \\
\hline $\begin{array}{l}\text { The revision BMLR 2008/09 } \\
\text { affects the role of the AC. }\end{array}$ & $\stackrel{\infty}{\infty}$ & $\stackrel{0}{\infty}$ & $\stackrel{\infty}{\infty}$ & $\stackrel{\infty}{\infty}$ & $\stackrel{\infty}{\infty}$ & $\stackrel{0}{\partial}$ & $\stackrel{\infty}{\infty}$ & $\stackrel{0}{\infty}$ \\
\hline $\begin{array}{l}\text { The revision BMLR 2008/09 } \\
\text { affects the role of the IA. }\end{array}$ & 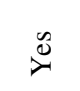 & 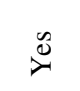 & $\stackrel{\infty}{\infty}$ & $\stackrel{\infty}{\approx}$ & $\stackrel{\infty}{\infty}$ & $\stackrel{0}{e}$ & 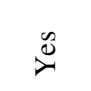 & $\stackrel{\infty}{\infty}$ \\
\hline Role of AC and IA & $>\underbrace{D}_{\square=}$ & $>\underbrace{2}_{\text {II }}$ & 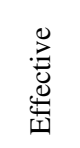 & 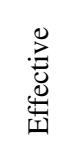 & 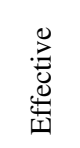 & 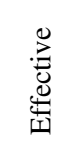 & 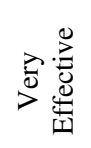 & 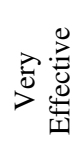 \\
\hline $\begin{array}{l}\text { The revision on the role of AC and } \\
\text { IAF contributes to the preparation } \\
\text { of financial statement audit. }\end{array}$ & $\stackrel{0}{0}$ & $\stackrel{0}{0}$ & 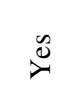 & $\stackrel{0}{0}$ & $\stackrel{0}{0}$ & $\stackrel{\theta}{0}$ & $\stackrel{\theta}{\infty}$ & $\stackrel{\vec{\nu}}{\ddot{\theta}}$ \\
\hline $\begin{array}{l}\text { External auditor still needs to } \\
\text { conduct substantive audit testing. }\end{array}$ & $\stackrel{0}{\infty}$ & $\stackrel{0}{\infty}$ & $\stackrel{0}{\nu}$ & $\stackrel{\Xi}{\infty}$ & $\stackrel{0}{0}$ & $\stackrel{0}{\nu}$ & $\stackrel{0}{\nu}$ & $\stackrel{\theta}{\infty}$ \\
\hline $\begin{array}{l}\text { Does the contribution of the IA } \\
\text { assist in reducing external audit } \\
\text { fees? }\end{array}$ & ż & ż & Z & $\stackrel{\theta}{0}$ & 之 & Z & z & $\stackrel{\theta}{\Delta}$ \\
\hline $\begin{array}{l}\text { The audit fee is lowest in the } \\
\text { region. }\end{array}$ & 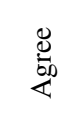 & 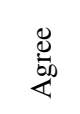 & 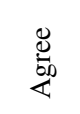 & 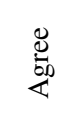 & 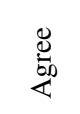 & 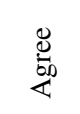 & 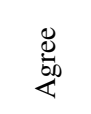 & 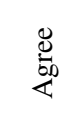 \\
\hline $\begin{array}{l}\text { Most of the PCON companies } \\
\text { complied with the BMLR } 2008 \\
\text { even before it became mandatory. }\end{array}$ & 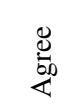 & 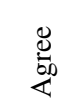 & 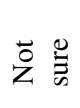 & 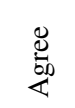 & $\overrightarrow{0}$ & 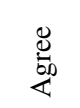 & 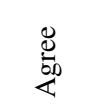 & 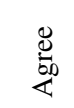 \\
\hline
\end{tabular}


To ensure that the audit committee serves as an effective check on the management of a company, the BMLR 2008 spells out the composition of audit committees, the frequency of meetings, and the need for audit committee members to attend continuous training to keep abreast of developments in relevant financial and other related developments. In addition, executive directors are no longer allowed to become members of the audit committee in order to preserve the independence of the committee.

Thus, more research needs to be conducted to understand the impact of BMLR 2008 on audit fees. This present study interviews eight respondents, i.e., three internal auditors, three external auditors and two regulators to obtain their perceptions on this. Interestingly, all eight respondents concur that the BMLR 2008 has improved the role of AC and IAF in the governance of a listed firm. This is consistent with Cohen et al. (2002) who find that corporate governance developments have increased the focus on internal control systems, and the internal audit function has been identified as having a key role in assessing and improving the quality of such a system. Further, the audit committee plays a crucial role in improving the firm's internal controls through its monitoring of the work of the internal and external auditors (Collier, 1992). Thus, it is anticipated that internal controls are stronger in companies that have an effective and efficient audit committee; as noted by interviewee IA3:

"Audit committee involvement towards internal audit activities was not critical before, as they were only looking at reports. But now they are very much involved, and the interaction between the audit committee and the head of internal auditors is good. As per last year, the company had seven or eight audit committee meetings, and we even had a meeting without the presence of the management."

IA1, noting a similar viewpoint, states that:

"Corporate governance in Malaysia is good and will be better due to the support from Bursa Malaysia. Compared to previous years, a lot of differences have taken place, especially in 2008, due to the additional roles of the audit committee and the internal audit function."

Hence, the new requirements by Bursa Malaysia further strengthen the role and responsibilities of an audit committee vis-a-vis the internal audit function, such as reviewing the adequacy, functions, competency, and the resources of the internal audit and other audit activities. The audit committee has the ability to enhance the effectiveness of the internal audit function, and, in turn, this has implications for the contribution of internal auditors to the external audit work.

All eight (8) respondents agree that the internal audit function contributes to the financial statement audit. The internal auditors provide reasonable assistance to their external auditors in areas that need clarification, but they are not directly involved in the preparation of the financial statement. However, they do provide assistance to their external auditors during the course of the audit in various ways including getting more information about internal control systems in the organization. Normally, external auditors will review the internal auditors' work, 
and, if the work of the internal auditors is of reasonable quality, they tend to use the work completed by the internal auditors, particularly in areas, such as internal control reviews.

Notwithstanding the role played by the internal auditors, when queried whether such assistance rendered by the internal auditors has any impact on audit fees, most respondents claim that the contribution of the internal audit does not result in a reduction in the external audit fees. This is because external auditors tend to cover areas that are not fully covered by the internal auditors. Further, as one of the respondents (IA3) said:

"The external auditor does not fully rely on the internal auditors' report, but they will drop by at the internal audit department to get information that they will use in doing the audit. The external auditor only relies on controls but not financial matters because they have to be assured and need to do their own verification and testing."

Nevertheless, there are respondents who believe otherwise. For instance, EA2 said that the amount of audit fees charged is usually fixed and agreed upon before the external auditor is appointed. However, as audit fees are charged based on audit hours and the number of staff assigned to audit the audit client, the fixed fees charged can be less if the number of audit hours and auditors are reduced. Thus, if the external auditors can rely on the internal audit work, the audit fees can be reduced. However, before the external auditors rely on the internal audit, they must be assured that the information is reliable, and the quality of internal audit function is of high quality. According to one of the respondents (EA3) interviewed by the researcher:

"If the internal audit standards are met, the reliance on IAF can be in full, but if the firm does not meet the standards, we can rely to a certain extent but not to reduce our work. It can reduce the audit effort but not that much."

Further, respondent R1 commented that:

"External auditors do not rely on internal audit function because they need to give their own opinion on how internal control and governance mechanisms are operating in the company. Reliance does not absolve them from their responsibilities. Good corporate governance may reduce the audit work to a certain extent because they need to focus on areas that are not being covered. External auditors need to assess and review the internal audit function before they can put some reliance."

Interestingly, the findings indicate that the greater the objectivity, technical competence and quality of work performance, the larger the potential for internal auditors to contribute to the external audit (Krishnamoorty et al., 2002). Additionally, audit fees are also dependent on the level of substantive testing required (Sherer \& Turley, 1991). The external auditors do cover areas that are not included in the internal audit work. Although the external auditor may rely on the internal audit work and reduce the substantive testing resulting in lower 
audit fees, the external auditor cannot do so if compliance tests indicate that internal controls are not operating properly. Further, Devi, and Samujh (2010) find that Malaysia's audit fees are still the lowest in the ASEAN region and this might be a reason for no reduction of audit fees despite reliance by the external auditor on the audited clients' internal audit function. This is supported by the respondent (IA1) interviewed in this current study, who claimed that:

"With the changes in regulation, the role and responsibilities of the audit committee and internal audit function are more; external auditors can rely on the job function of the audit committee and internal audit function; however, the amount of audit fees charged would not be reduced but keeps on increasing every year. This is because audit fees in Malaysia are the lowest in the region."

Likewise, another respondent (EA3) in this study also highlighted that:

"In Indonesia, audit fees are paid in US dollars unlike in Malaysia. Our audit fees are the lowest in the region, and it will never reduce because the work and effort that we have to put in are great."

\subsection{Perceptions on the Internal Governance Mechanisms and Audit Fees for Politically Connected Companies}

Prior studies have shown that the presence of government ownership gives rise to inefficiencies and poor performance (Megginson, Nash, \& Randenborgh, 1994; Megginson \& Netter, 2001; Johnson \& Mitton, 2003) to the government favoured companies. According to Mak and Li (2001), the government is likely to be less active in monitoring their investments in these companies. As a result, weaker accountability for financial performance, easier access to financing, lack of exposure to a market for corporate control, and weaker monitoring by shareholders are likely to reduce the incentives for PCON companies to adopt strong governance.

In addition, Gul (2006) evidences that favoured companies in Malaysia are closely connected to influential political figures. His study documents evidence of 'crony-capitalism' in Malaysia. The favoured companies' political linkages influence the accumulation and concentration of wealth in Malaysian business (Gomez \& Jomo, 1999). However, despite the close connection with the influential politicians, the favoured companies are conscious of good governance. From the interviews conducted in this current study, one of the interviewees (IA3) explained:

"Our company and other government-linked companies are very strict with corporate governance activities. We have a lot to lose if we do not comply because of government intervention. Same goes with politically connected companies, the political people on board must show their capabilities, they really need to comply if not they will fail. If government companies keep on failing, it doesn't look good on their track record, and, later on, it is difficult to ask assistance from the government." 
Likewise, another respondent (EA3) stated that:

"Probably, in the beginning, the politically connected companies had poor performance, and the corporate governance was not strong. But now they are strict and moving towards corporate governance and need to keep up with the KPIs. But still, certain companies that are subject to less focus from the government are a bit weak. However, they are also striving towards good corporate governance practices."

According to another respondent (IA1):

"Politically connected companies have lower risk because they are backed up by the government most of the time, and their corporate governance has improved, especially after 2005 due to the transformation programme."**

Table 3. Internal governance mechanisms and audit fees for politically connected companies

Content Theme: Perceptions on the enhanced CG for different types of ownership structure, specifically on PCON companies and audit fees implications

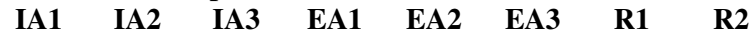

PCON companies are perceived

to have poor corporate

governance and riskier than non-

PCON companies.

The enhanced $\mathrm{CG}$ on $\mathrm{AC}$ and

IAF attributes affects PCON

companies the most.

\begin{tabular}{|c|c|c|c|c|c|c|}
\hline ㅇ & $\stackrel{\circ}{z}$ & $\stackrel{\infty}{\infty}$ & $\stackrel{0}{\infty}$ & z & $\stackrel{\circ}{z}$ & $\stackrel{\circ}{z}$ \\
\hline$\circ$ & $\stackrel{\circ}{z}$ & $\overrightarrow{0}$ & zo & $\overrightarrow{0}$ & zo & z \\
\hline
\end{tabular}

The government intervention is expected to produce better governance and improve the firm's business performance. In fact, through its representatives from the Ministry of Finance who sit on the board of directors, the government, which owns shares in these companies, can prevent any conflict of interest by the managers. The said representatives are responsible for controlling and monitoring the management activities. Hence, it can be said that there is an increase in the accountability and efficiency of the Malaysian PCON companies through the effective ownership by the government. Interestingly, from the interviews conducted in this study, six out of eight respondents agreed that most of the PCON companies complied with the BMLR 2008 even before it became mandatory. As confirmed by one of the respondents (IA3):

"PCON companies are formed under the Public Interest Entity (PIE); all requirements must be complied with, and all documentation for audit must be updated. If any new regulation imposed by Bursa PCON companies will have to implement them. Some of the companies complied with the regulations even before. It was voluntary during that time."

\footnotetext{
** Transformation Programme includes various strategies aimed at enhancing corporate developing social leaders and clarifying social leaders and upgrading the effectiveness of the Board.
} 
Likewise, another respondent (EA2) illustrated this point:

"The changes in regulations do not affect these companies that much because they are moving towards good governance. There were also companies complying with the good practices even before they became mandatory by Bursa."

The respondent (IA3) stressed that:

"The changes don't have any impact, they just want it to be clear and documented on the existence of requirements, but most of the companies already have that in place."

In summary, the launch of the Government Linked Companies (GLCs) Transformation Programme by the Malaysian government, among others, enhanced the performance of GLCs in 2005. The programme improved the corporate governance practices and was followed by politically connected companies. It is to be noted that one of the objectives of the programme is to upgrade the effectiveness of the board and reinforce the governance of the said companies. Further, the government expects its favoured companies to increase their investments and spending to make up for the shortfall arising from the government's move to cut its own expenditure and reduce the budget deficit (Najid \& Abdul Rahman, 2011).

With the continuous improvement in corporate governance practices, the PCON companies are perceived to have better corporate governance, and it is envisaged that these companies will reinforce this mind-set of continuous improvement in their day-to-day operations. This is important because Malaysian PCON companies were once perceived to be associated with higher business risk and poor performance. Therefore, it is crucial that their performance, which forms the backbone of the country's economy, should improve and make a significant contribution to the nation's development and create value for other key stakeholders. As explained by one of the respondents (IA3):

"PCON companies are not 100\% owned by government, we have shareholders and private owners, to whom we are also liable. We are answerable to these people. I don't agree that PCON companies carry higher risk and poor performance. We have a lot of things in place and complying with all these requirements."

\section{Conclusion}

In summary, the interviews provide a more in-depth understanding of the relationship between the enhanced BMLR 2008 on AC characteristics and IAF, and its implications for audit fees for PCON companies. To dispel the negative perceptions of PCON companies, the Malaysian government implemented steps to enhance their corporate governance practices. The results of this study show that the PCON companies have better governance mechanisms. From the findings of the interviews, the interviewees suggest that PCON companies have been complying with the listing requirements specifically in relation to $\mathrm{AC}$ 
characteristics and IAF attributes. Audit committees have a duty not just for overseeing the conduct of business in compliance with laws, but also as effective stewards and guardians of the firm in respect of ethical values, and for ensuring an effective governance structure for the appropriate management of risks and level of internal controls. Their involvement in strengthening internal controls is more likely to demand higher audit quality in order to protect their reputation, and, at the same time, does not compromise the quality of the audit. The interviews also highlighted that PCON companies engage in a greater level of internal monitoring through the use of internal audit, which also demands higher quality external auditing. This is because they recognize the importance of both types of audit as mechanisms to strengthen corporate governance; thus, they complement each other's work. Due to this reason, the audit committee members of PCON companies would demand that the external auditor conduct substantive audit work and be willing to pay higher audit fees. This also indicates that regulatory oversight plays a vital role in enhancing good corporate governance practices and that it complements the external audit as a monitoring mechanism. The interviews also evidenced that the extent of external auditor reliance on the internal audit function may not necessarily lead to a reduction in audit fees. It appears that the majority of the interviewees agreed that, to a certain extent, the external auditors are able to place some reliance on internal audit contribution. However, it would not assist in reducing the external audit fees, and the PCON companies still pay higher audit fees. In sum, this study reveals that good corporate governance practices have been effectively implemented in PCON companies and that the demand side explanation prevails.

\section{References}

Abbott, L. J., Parker, S., \& Peters, G. F. (2004). Audit committee characteristics and restatements. Auditing: A Journal of Practice \& Theory, 23(1), 69-87.

Abbott, L. J., Parker, S., Peters, G. F., \& Raghunandan, K. (2003) An empirical investigation of audit fees, non-audit fees and audit committee. Contemporary Accounting Research, 20(2), 215-234.

Abbott, L. J., Parker, S., Peters, G. F., \& Raghunandan, K. (2003). The association between audit committee characteristics and audit fees. Auditing: A Journal of Practice and Theory, 22(2), 17-32.

Abdul Rahman, R. (2006). Effective Corporate Governance: UPENA.

Abdul Wahab, E. A., Mat Zain, M., \& James, K. (2011). Political connections, corporate governance and audit fees in Malaysia. Managerial Auditing Journal, 26(5), 393-418.

Abdul Wahab, E. A., Mat Zain, M., James, K., \& Haron, H. (2009). Institutional investors, political connection and audit quality in Malaysia. Accounting Research Journal, 22(2), 158-167.

Beasley, M. S., Carcello, J. V., Hermanson, D. R., \& Lapides, P. D. (2000). Fraudulent financial reporting consideration of industry traits and corporate governance mechanisms. Accounting Horizons, 14(4), 441-454. 
Bedard, J. C., Johnstone, K. M., \& Ettredge, M. (2004). The effect of competitive bidding on engagement planning and pricing. Contemporary Accounting Research, 21(1), 25-53.

BRC (Blue Ribbon Committee). (1999). Report and Recommendations of the Blue Ribbon Committee on Improving the Effectiveness of Corporate Audit Committees (New York, NY: New York Stock Exchange and National Association of Securities Dealers).

BMSB (Bursa Malaysia Sdn Bhd). (2001). Listing Requirements of Bursa Malaysia Securities Berhad. Kuala Lumpur. Retrieved from http://www.bursamalaysia.com/

BMSB (Bursa Malaysia Sdn Bhd). (2008). Listing Requirements of Bursa Malaysia Securities Berhad. Kuala Lumpur. Retrieved from http://www.bursamalaysia.com/

Carcello, Hermanson, Neal, and Riley, R. J. (2002). Board characteristics and audit fees. Contemporary Accounting Research, 19(3), 365-384.

Chung, H. H., \& Wynn, J. P. (2014). Corporate governance, directors' and officers' insurance premiums and audit fees. Managerial Auditing Journal, 29(2), 173-195.

Cohen, J. R., Krishnamoorthy, G., \& Wright, A. M. (2002). Corporate Governance and the audit process. Contemporary Accounting Research, 19(4), 573-594.

Collier, P. (Ed.). (1992). Audit Committees in Large UK Companies, London: ICAEW.

Dechow, P. M., Sloan, R. G., \& Wong, T. J. (1996). Causes and consequences of earnings manipulation: an analysis of firms subject to enforcement actions by the SEC. Contemporary Accounting Research, 13(1), 1-36.

Devi, S. S., \& Samujh, R. H. (2010). Accountants as providers of support and advice to SMEs in Malaysia (Research report No. 118). ACCA, London.

Fields, L. P., Fraser, D. R., \& Wilkins, M. S. (2004). An investigation of the pricing of audit services for financial institutions. Journal of Accounting and Public Policy, 23(1), 53-77.

Gomez, E. T., \& Jomo, K. S. (1999). Malaysia's Political Economy: Politics, Patronage and Profits. Cambridge University Press, Cambridge.

Goodwin, S. J., \& Kent, P. (2006). Relation between external audit fees, audit committee characteristics and internal audit. Accounting and Finance, 46(3), 387-404.

Gul, F. A. (2006). Auditor's responses to political connections and cronyism in Malaysia. Journal of Accounting Research, 44(5), 931-963.

Hackenbrack, K., \& Knechel, W. R. (1997). Resource allocation decisions in audit engagements. Contemporary Accounting Research, 14(3), 484-499.

Hallak, R. T. P., \& Silva, A. L. C. (2012). Determinantes das despesas com serviços de auditoria e consultoria prestados pelo auditor independente no Brasil. Revista Contabilidade \& Finanças, 23(60), 223-231.

Haniffa, R. M., \& Cooke, T. E. (2002). Culture, corporate governance and disclosure in Malaysian corporations. Abacus, 38(3), 317-349. 
Hadjikhani, A., \& Håkansson, H. (1996). Political actions in business networks: A Swedish Case. International Journal of Research in Marketing, 13(5), 431-447.

Hay, D. (2012). Further Evidence from meta-analysis of audit fee research. International Journal of Auditing, 17(2), 162-179.

Hay, D., Knechel, W. R., \& Ling, H. (2008). Evidence on the impact of internal control and corporate governance on audit fees. International Journal of Auditing, 12(1), 9-24.

How, J., Verhoeven P., \& Effiezal, A. (2014). Institutional investors, political connections and analyst following in Malaysia. Economic Modelling, 43, 158-167.

Johnson, S., \& Mitton, T. (2003). Cronyism and capital controls: evidence from Malaysia. Journal of Financial Economics, 67(2), 351-382.

Klein, A. (2002). Audit committee, board of director's characteristics and earnings management. Journal of Accounting and Economics, 33(3), 375400.

Krishnamoorthy, G., Wright, A., \& Cohen, J. (2002). Auditors' views on audit committees and financial reporting quality. CPA Journal, 72(10), 56-62.

Krishnan, J., and Ye., Z. (2005). Why some firms solicit shareholders' voting on auditor selection. Accounting Horizons, 19(4), 237-243.

Lifschutz, S., Jacobi, A., \& Feldshtein, S. 2001. Corporate governance characteristics and external audit fees: A Study of large public companies in Israel. International Journal of Business and Management, 5(3), 109-116.

Liu, L. \& Subramaniam, N. (2013). Government ownership, audit firm size and audit pricing: Evidence from China. Journal of Accounting and Public Policy, 32(2),161-175.

MCCG (Malaysian Code of Corporate Governance). (2012). Malaysian Law Journal Sdn. Bhd., Malaysia.

MCCG (Malaysian Code of Corporate Governance). (2007). Malaysian Law Journal Sdn. Bhd., Malaysia.

Mak, Y. T., \& Li, Y. (2001). Determinants of Corporate Ownership and Board Structure: Evidence from Singapore. Journal of Corporate Finance, 7(3), 236-256.

Megginson, W. L., Robert C. N., \& van Randenborgh, M. (1994). The financial and operating performance of newly privatized firms: An international empirical analysis, Journal of Finance, 49(2), 403-452.

Megginson, W. L., \& Jeffry M. N. (2001). From State to Market: A Survey of Empirical Studies on Privatization. Journal of Economic Literature, 39(2), 321-389.

Mohamad, S., Hassan, T., \& Chen, C. M. (2006). Impact of political-business relationship: ownership patterns and corporate performance in Malaysia. Paper presented at the 2006 Asian Finance Association Conference, Kuala Lumpur, Malaysia. 
Najid, N. A., \& Abdul Rahman, R. (2011). Government Ownership and Performance of Malaysian Government-Linked Companies. International Research Journal of Finance and Economics, 61(2): 42-48.

O'Keefe, T. B., Simunic, D., \& Stein, M. T. (1994). The production of audit services: evidence from a major public accounting firm. Journal of Accounting Research, 32(2), 241-261.

O'Sullivan, N. (1999). Board characteristics and audit pricing post-Cadbury: A research note. European Accounting Review, 8(2), 253-263.

O'Sullivan, N. (2000). The impact of board composition and ownership on audit quality: Evidence from large UK companies. British Accounting Review, 32(4), 397-414.

Prawitt, D. F., Sharp, N. Y., \& Wood, D. A. (2008). Does internal audit quality affect the external audit fees? Paper presented at the 2006 BYU Accounting Research Symposium.

SEC (Securities and Exchange Commission) (1999). Annual Report, United States Congress.

SC (Securities Commission Malaysia) (2016). Retrieved from http://www.sc.com.my/

Sherer, M., \& Turley, S. (Eds.). (1991). Current issues in auditing. Paul Chapman Publishing, London.

Simunic, D. A. (1980). The pricing of audit services: Theory and evidence. Journal of Accounting Research, 18(1), 161-190.

Walker, P. L., \& Casterella, J. R. (2000). The role of auditee profitability in pricing new audit engagements. Auditing: A Journal of Practice and Theory, 19(1), 157-167.

World Bank. (2001). Malaysia - Report on the Observance of Standards and Codes (ROSC): corporate governance country assessment (English). Washington, DC: World Bank Group. Retrieved from http://www.worldbank.org/

World Bank. (2005). Malaysia - Report on the Observance of Standards and Codes (ROSC): corporate governance country assessment (English). Washington, DC: World Bank Group. Retrieved from http://www.worldbank.org/

World Bank. (2012). Malaysia - Report on the Observance of Standards and Codes (ROSC): corporate governance country assessment (English). Washington, DC: World Bank Group. Retrieved from http://www.worldbank.org/

Yatim, Kent, P., \& Clarkson, P. (2006). Governance structures, ethnicity and audit fees of Malaysian listed firms. Managerial Auditing Journal, 21(7), 757-782. 